\author{
Dorota PERŁO, PhD \\ Faculty of Economics and Management, The University of Bialystok \\ e-mail: dorota.perlo@uwb.edu.pl
}

Ewa ROSZKOWSKA, PhD, Professor of the University of Bialystok Faculty of Economics and Management, The University of Bialystok e-mail: erosz@o2.pl

\title{
THE APPLICATION OF SOFT MODELLING AND TOPSIS METHOD FOR THE ANALYSIS OF COMPETITIVENESS OF COMPANIES IN URBAN FUNCTIONAL AREAS IN POLAND
}

\begin{abstract}
Summary
The aim of the paper is to use soft modelling and TOPSIS method in order to divide voivodeships in terms of the competitiveness level of companies. The paper verifies the hypothesis implying that the usage of two various research methods does not have considerable impact on the position of objects depending on the analyzed characteristic. The concluding part of the paper includes the comparison of the results of grouping objects obtained using the selected methods. The elaboration makes use of data from the year 2014.

The results obtained on the basis of these two methods enabled the presentation of the competitiveness level of companies in urban functional areas in Poland as well as the possibilities of achieving competitive advantage by means of using additional funds from the European Union for the improvement of the conditions of their functioning.
\end{abstract}

Key words: competitiveness of companies, urban functional areas, soft model, TOPSIS method.

JEL Classification: C31, R12, R58

\section{Introduction}

In the conditions of globalization the activity of companies on the market is not limited in spatial terms. The key indicator of both their functioning and the perspectives of further development becomes competitiveness which is an inseparable characteristic of market economy. As a phenomenon it has many aspects, depends on a branch and sector and may take place on many levels and be manifested in various forms. Competitiveness has relative character because while making the assessment of the company's competitiveness level one faces the problem of selecting proper reference points and adopting appropriate criteria and measures [Luka konkurencyjna na poziomie przedsiebiorstwa... 2002]. The competitiveness of companies is a derivative of economic competitiveness of 
a country, region or municipality. It is significant to recognize and understand both the conditionings and factors that determine it.

In accordance with the definition approach adopted by OECD, competitiveness is "the country's capacity to make goods and services that in the conditions of free and fair trade are acceptable on the global market while maintaining and increasing the real incomes of population in the long time period" [Lubiński, 1995, p. 8]. Meanwhile, in a more detailed degree "competitiveness means both the capacity of companies, industries, regions, nations or supranational groups to face international competitiveness and guarantee a relatively high rate of return from the used production factors and also relatively high employment level having stable bases" [Lubiński, 1995, p. 9]. Owing to this the competitiveness of companies can be viewed as a system created by such elements closely connected with one another as [Stankiewicz, 2000, p. 79]:

- potential of competitiveness, the entirety of material and non-material resources of a company, capabilities and essential competences enabling the achievement of stable competitive advantage over competitors that will be difficult to undermine;

- $\quad$ competitive advantage which has relative character and can be perceived as the effect of using effectively the configuration of the elements of competitiveness potential that enable a company to create an attractive offer on the market and efficient instruments of competitiveness;

- competing instruments defined as deliberate and purposefully used instruments and methods of creating the capital of customers and creating the value of a company;

- $\quad$ competitive position which ought to be understood as the result of competing achieved by a company in a particular sector that can be compared with the results achieved by competitors.

Owing to this the competitiveness level of companies is determined by their potential. Meanwhile, the potential is dependent on a multitude of diverse factors, among which the most crucial factor appears to be the dimension of a company. Large international corporations have different possibilities of building competitive advantage than small and medium-sized companies. However, nowadays the SME sector in the most considerable degree contributes to the creation of GDP of all the European economies. While making decisions regarding the location of the investment companies draw attention to such factors as the attractiveness of places with a view of making investment. They frequently concentrate their operation in the main cities of particular voivodeships that constitute the poles of the regional development. In this aspect there may be observed certain feedback. Companies select the most attractive locations, while cities attempt to select the best investments and as the consequence are concerned about creating considerably better conditions that will encourage entrepreneurs to select their cities as the most beneficial locations. In the financial perspective of the European Union (2014-2020) there was formed a new instrument of support for district cities and their functional areas, i.e. Integrated Territorial Investments (ITI) [tem 19, art. 7, act 1 of the Decree of the European Parliament and the Council (EU) No. 1301/2013, art. 36 act 1 of the Decree of the European Parliament and the Council (EU) No. 1303/2013; art. 12 act 2 of the Decree of the European Parliament and the Council (EU) No. 
1304/2013; art. 30 act 5, item 2 of the Act on the principles of realizing policy cohesion programs..., [Programowanie perspektyny finansowej 2014-2020 ... 2014, pp. 213, 215]. Other cities, termed as the sub-regional ones, may use similar financing in the form of Regional Territorial Investments (RTI). Investors are attracted mostly by cities and a potential location of financial institution offices or widely understood service offer, and the surrounding of cities is a perfect investment area for industrial operations, among others, owing to the available economic infrastructure, which may result in increasing the competitiveness of companies and indicates the necessity to make investments in the city as regards the conditions in which companies are functioning.

The aim of the paper is to use soft modelling and TOPSIS method for dividing voivodeships in terms of the competitiveness level of companies. The paper includes the hypothesis implying that the usage of two various research methods does not have considerable impact on the location of objects depending on the analyzed characteristic. The obtained results facilitated the presentation of the competitiveness level of companies in urban functional areas in Poland and the possibilities of achieving competitive advantage owing to the involvement of additional funds from the European Union for the improvement of conditions of their functioning.

The research was conducted on the basis of the statistical data available in the Central Statistical Office of Poland and in the Customs Office (both institutions are located in Warsaw). The analysis was conducted on the cross-sectional group comprising both voivodeships in Poland and urban functional areas in Poland. Data regards the year 2014 and the prediction of the allocation dimension of Integrated Territorial Investments in Poland for the year 2020.

\section{Research methodology}

In the research there were used two methods: soft modelling and TOPSIS method. This particular choice results from the fact that these methods enable the construction of synthetic indicators and making ranking of objects on the basis of these indicators.

Each soft model is composed of two elements: internal (theoretical) model and external model (measuring model) Joreskog, Wold, 1982; Rogowski, 1990; Rogowski, 2002, pp. 23-34]. The models are interrelated, which means that both of them are used in the process of estimating parameters. The internal model describes the relations between the non-observable variables, i.e. it describes the theoretical relations ensuing from the adopted theory. The application of the analyzed method requires making the assumption that the relations in soft models have linear character. The second model - measuring model - shows in what way indicators reflect their hidden variables, i.e. it includes the definitions of theoretical variables. In case of the soft model it is assumed that hidden variables are the linear combinations of their indicators (these are the so called weight relations): 


$$
\mathrm{V}_{j=1, \ldots, k} \mathrm{~V}_{t=1, \ldots, T} \xi_{j t}=\sum_{i=1}^{n_{j}} w_{i j} x_{i j t}
$$

where:

$\xi_{j t}-$ is the $j$-th value of hidden variable,

$x_{i j t}$ - the $t$ value of observable value $\mathrm{x}_{\mathrm{ij}}$, i.e. $i$ indicator of $j$-th hidden variable,

$\mathrm{T}$ - the number of the analyzed objects for cross-sectional data or for the observation moments for time series.

There is also a relation describing the power of reflecting the non-observable variable by its indicator:

$$
\bigvee_{j=1, \ldots, k} \bigvee_{t=1, \ldots, T} \mathrm{x}_{i j}=p_{i j 0}+p_{i j} \xi_{j t}+\mu_{i j t}
$$

where:

$p_{i j 0}$ - free expression of the relation,

$p_{i j}$ - factor loading measuring the "reflecting" power of hidden variable by its $i$-th indicator $x_{i j}$

$\mu_{i j}$ - random element.

Non-observable variables may be defined in two ways: using deduction or induction. Depending on the approach there are observed differences in the manner and results of the estimation. The authors adopted the deductive approach which implies that a hidden variable (as a theoretical concept) is the starting point for seeking empirical data (transition from the theoretical concepts to indicators), which means that this variable is primary in relation to a certain indicator. The indicators of this type of non-observable variables are termed as reflective indicators. In principle, reflective indicators ought to be characterized by high correlation between one another. Therefore, during the selection of variables it is recommended to draw attention to substantive aspects instead of choosing the classical methods of selection. It is due to the fact that classical methods indicate insignificant dependence between the explanatory variables [Kuszewski, 2000, pp. 14-16].

Soft model is estimated using the PLS method (partial least squares). The estimation of the soft model takes place in three stages:

- $\quad$ iterative estimation of weight which enables the estimation of the values of hidden variables;

- estimation of the parameters of the internal and external model (factor loadings);

- $\quad$ estimation of the expressions of free internal and external relations.

The attempt to estimate the parameters of the soft model using PLS method ought to be preceded by the unification of all the observable variables in order to make the observations independent from the measuring units and the orders of magnitude of 
indicators. There are various normalization methods [Dębkowska, Jarocka, 2013, pp. 181-188]. In this paper standardization was used for soft modelling.1.

In the PLS method there may be observed simultaneous estimation of the parameters of the measuring model and the theoretical model. Apart from these parameters the estimation results in the specification of the hidden variable which may be considered as a synthetic measure. These values are dependent not only on the external relations, but also on the relations between the complex phenomena specified in the internal model. It means that the cognition process is reliant on the theoretical description. The estimations of non-observable variables do not have substantive interpretation, but it is possible to interpret the changes of their values. The variables analyzed in soft modelling are termed as stimulants or destimulants. If the estimators of weight and factor loadings for the estimators being the stimulants of a certain observable data are positive, while those being destimulants are negative, the higher value of this variable indicates greater degree of the observed phenomenon in a certain object. By interpreting the sequence of these numbers a comparative analysis is made.

Prior to initiating the analysis of the ordering results obtained on the basis of the soft model it is necessary to conduct its verification. Initially the verification has substantive character (similar to the classical econometric model), but afterwards a statistical verification is made. The assessment of the parameters of external and internal relations must conform to the adopted theoretical description. In order to verify the quality of the soft model one may use the measuring standards of "classical" econometrics and perceive the estimated values of hidden values as the values observed in the reality. In this way there are calculated $\mathrm{R}$-squared coefficients of multiple correlation $\left(\mathrm{R}^{2}\right)$ or, for example, standard deviations of the parameter estimators.

The statistical characteristics of the soft model are checked mainly on the basis of Stone-Geisser test (S-G test) which constitutes the precision measure of the prediction made on the basis of the model in relation to the "trivial" prediction and using the method of the so called Tukey test [Rogowski, 1990]. These methods are specific for soft modelling. S-G test (the term created by H. Wold) is not a typical statistical test because it does not include any hypotheses, statistics or critical values. The procedure of analyzing the importance of variables is completely different since it constitutes a certain type of a trial, not a statistical test. The bottom values of the S-G test are not limited, whereas the upper limitation is 1 . If the test value is negative, a certain soft model has worse predictive attribute in relation to the trivial prognostication. When the test value is 1 , the prognoses are correct, whereas for the value amounting to 0 , the quality of the model prognosis and the trivial prognosis are identical.

Standardized $t$ value of $i$ indicator of hidden variable $z_{i j t}(j=1, \ldots, k ; i=1, \ldots, n ; t=1, \ldots, T)$ is calculated in accordance with the formula:

$$
z_{i j t}=\frac{x_{i j t}-\bar{x}_{i j}}{s_{i j}}, \text { where } \bar{x}_{i j}=\frac{\sum_{t=1}^{T} x_{i j t}}{T}, s=\sqrt{\frac{\sum_{t=1}^{T}\left(x_{i j t}-\bar{x}_{i j}\right)}{T}} .
$$


In order to calculate the value of S-G test it is necessary to estimate $\mathrm{L}$ times the parameters of the soft model. For each parameter $\beta$ of the external and internal relation there may be specified standard deviation of the obtained L of its estimators: $b_{1}$, $\mathrm{b}_{2}, \ldots, \mathrm{b}_{\mathrm{L}}$ in accordance with the formula:

$$
s_{\beta}=\sqrt{\frac{\sum_{l=1}^{L}\left(b_{l}-\bar{b}\right)^{2}}{L}} \text {, where } \bar{b}=\frac{\sum_{l=1}^{L} b_{l}}{L}
$$

In this situation the assessment of the importance of the model parameters is made using the principle of " $2 \mathrm{~s}$ ". This method is termed as the "method of Tukey test".

For the construction of rankings of regions in terms of the competitiveness level of companies in urban functional areas in Poland there may be used methods of multidimensional comparative analysis where in the construction of synthetic measure of development two approaches are applied: non-model approach and model approach of development [Młodak, 2006]. In order to analyze the problem the authors of this publication used TOPSIS procedure based on both the model approach and non-model approach of development. In the first stage there were selected diagnostic characteristics in accordance with both the substantive and statistical premises, the so-called attributes which, in the light of the prevailing substantive knowledge, properly describe a certain phenomenon as well as those attributes that are characterized by high variability and low correlation level. At the same time attributes were divided into two groups: the ones with higher values being the evidence of better position of the region owing to the analyzed phenomenon (stimulants) and those with desired lower level (destimulants) [Panek, 2009, p. 17; Młodak, 2006].

For the construction of a synthetic measure there were adopted identical weight coefficients for all indicators. Particular stages of TOPSIS procedure are as follows [Hwang, Yoon, 1981]:

Stage 1. The construction of the indicator matrix:

$$
X=\left[x_{i k}\right],
$$

where: the value of this indicator for the voivodeship

Stage 2. Normalization of the values of indicators aiming at achieving their comparability:

- for stimulants:

$$
z_{i k}=\frac{x_{i k}-\min _{i}\left\{x_{i k}\right\}}{\max _{i}\left\{x_{i k}\right\}-\min _{i}\left\{x_{i k}\right\}}
$$

- for destimulants:

$$
z_{i k}=\frac{\max _{i}\left\{x_{i k}\right\}-x_{i k}}{\max _{i}\left\{x_{i k}\right\}-\min _{i}\left\{x_{i k}\right\}}
$$

where:

$k-$ the number of the indicator $(k=1,2, \ldots, m)$, 
$i$ - the number of the voivodeship $(i=1,2, \ldots, 16)$

- $\max _{i}\left\{x_{i k}\right\}$ - the maximum value of $k$ - indicator

- $\quad \min _{i}\left\{x_{i k}\right\}$ - the minimum value of $k$ - indicator

Stage 3. The calculation of the Euclidean distance of the regions from the model $\left(z_{i k}^{+}\right)$and anti-model $\left(z_{i k}^{-}\right)$of development in accordance with the formulae:

$$
d_{i}^{-}=\sum_{k=1}^{m} \sqrt{\left(z_{i k}-z_{i k}^{-}\right)^{2}}, d_{i}^{+}=\sum_{k=1}^{m} \sqrt{\left(z_{i k}-z_{i k}^{+}\right)^{2}}
$$

where:

$z_{i k}^{+}=(1,1, \ldots, 1)-$ patern of development,

$z_{i k}^{-}=(0,0, \ldots, 0)-$ anty-patern of development, $k=1,2, \ldots, m ; i=1,2, \ldots, 16$.

Stage 4. The calculation of the value of synthetic measure of the assessment of ith a certain voivodeship according to the formula:

$$
q_{i}=\frac{d_{i}^{-}}{d_{i}^{-}+d_{i}^{+}}
$$

where: $k=1,2, \ldots, m ; i=1,2, \ldots, 16$.

It is noteworthy that $0 \leq q_{i} \leq 1$. Higher values of the measure serve as the evidence of the higher position of the voivodeship in the ranking.

Stage 5. The linear ordering of regions owing to the value of synthetic measure of development and the division of voivodeships into four classes.

By using the arithmetic mean $(\bar{q})$ and standard deviation $(s)$ for the values of synthetic measure, voivodeships were divided into 4 classes in accordance with the formula:

- $\quad$ class I (high level): $q_{i} \geq \bar{q}+s$

- $\quad$ class II (upper medium level): $\bar{q}+s>q_{i} \geq \bar{q}$;

- $\quad$ class III (lower medium level): $\bar{q}>q_{i} \geq \bar{q}-s$;

- $\quad$ class IV (low level): $q_{i}<\bar{q}-s$.

\section{Competitiveness of companies in urban functional areas in Poland - soft model}

The level of economic growth of cities has impact on the shaping of other aspects of development that are related to the living standard and quality. The inhabitants satisfied with living in the city and having satisfactory job do not make any migration plans. The tax returns obtained from their incomes constitute the essential source of revenues for local governments. The level of economic growth of cities has impact on the shaping of other aspects related to the living standard and quality. Therefore, in a regional development policy it is essential to support the activities resulting in the improvement of competitiveness of companies and attracting new economic investments. In order to illustrate the competitiveness level of companies in urban functional 
areas there was used analysis of the indicators of strategic monitoring in the sphere of the Thematic Objective 3 (СT3) of the European Union Enhancing the competitiveness of small and medium-sized enterprises (SMEs), agriculture sector and fishing and aquaculture sector. The indicators were selected on the basis of the analysis of sixteen regional operational programs and the Partnership Agreement [Programowanie perspektyny finansowej..., 2014; Monitorowanie strategiczne miejskich obszarów funkcjonalnych..., 2016]. The indicators are aggregated on the level of regions. Therefore, during the construction of the model the authors used the voivodeship level NUTS2, instead of urban functional areas (UFA) which are the main subject of the research. The analysis of individual indicators of strategic monitoring and their dependence on the assumed allocation of ITI in the CT3 sphere does not enable drawing unvarying conclusions regarding the anticipated impact on the competitiveness level of companies in CT3 area. A good instrument for showing the aforementioned dependence is the soft model [Perło, 2014; Rogowski, 1990; Wold, 1980].

Among 14 strategic indicators from the third thematic objective FIDE were positively verified [Monitorowanie strategiczne..., 2016, pp. 30-31]. These are:

- Investment rate in the national economy (SIP_14),

- Participation of companies (companies of non-financial sector) obtaining orders using computer networks (Internet website, such systems as EDI) in companies altogether (PES_14),

- Participation of the area of offered investment areas in the total area of urban built-up areas in \% (TIN_14),

- The average participation of innovative companies in the total number of industrial companies and from the service sector (IPU_14),

- The percentage of industrial companies that cooperated with one another in the sphere of investment activity (IPW_14).

All the analyzed indicators that have considerable positive impact on the level of entrepreneurship in the analyzed regions are stimulants. The results of the estimation of weight and factor loadings of the analyzed indicators precisely meet the expectations and are positively verified using the method of the so-called Tukey test (graph 1, table 1).

The investment rate in the national economy (SIP_14) is the per cent relation of gross expenditures spent on fixed assets in the national economy to the value of gross domestic product. It is the indicator considered in the monitoring of both in the regional operational programs and in the Partnership Agreement. It is characterized by considerable impact on the competitiveness level of companies $(0,6896)$. Its value is dependent on two elements creating a numerator and denominator of the indicator. Therefore, the investment rate not always reaches the highest values in the regions characterized by the highest level of gross domestic product. In 2014 the lowest investment rate was in such voivodeships as: Podlaskie, Podkarpackie or Zachodniopomorskie.

The participation of companies (with regards to the non-financial sector) receiving orders via computer networks (Internet website, systems like EDI) in companies altogether (PES_14) is the indicator characterized by the lowest influence on the thematic objective 3 among all the positively verified indicators $(0,4191)$. The dynamic development of e-commerce market as well as its influence on the financial situation of companies seeking new sales markets indicates the importance of this indicator. 
The participation of the offered investment areas in the total area of built-up urban areas in \% (TIN_16) is the indicator characterized by average impact on the analyzed area $(0,5226)$. The area of investment areas in most functional areas is the indicator of the product. This indicator may be renounced in order to avoid copying from various sources the information regarding the analyzed indicators. All the more that information regarding the total area of offered investment areas is not available in public statistics. Investment areas may be offered with various infrastructure as the consequence of which the data is not comparable in 100\%. Municipal offices constitute the best sources of credible information on this subject. However, the collection of data from 521 municipalities could be too time-consuming.

The average participation of innovative companies in the total number of industrial companies and service sector (IPU_14) is the most considerable indicator from the perspective of the competitiveness of companies. The development of innovative companies is crucial from the point of view of the development perspectives specified in the document Europe 2020, within the frameworks of intelligent development, with regards to knowledge-based economy.

The percentage of industrial companies that cooperated with one another in the sphere of investment activity (IPW_14) is the indicator characterized by having moderate influence on the analyzed area $(0,5886)$. The cooperation of companies within the frameworks of clusters (among others) very often may result in the added value in the form of effects that could not be achieved by companies on their own. It is related to reducing the costs of their activity. The indicator shows an important sphere having impact on the competitiveness of companies, but does not copy the information obtained from other sources.

Furthermore, within the frameworks of the hidden variable CT3 it was possible to define the synthetic indicator that comprises all the analyzed detailed indicators (14) and was calculated using the taxonomic method in conformity with the synthetic feature [Kolenda, 2006]. Its impact on the increase of competitiveness to reach 0,6606 may be specified as medium, slightly lower than some individual variables. This may be interpreted as the justification of the lack of the requirement to analyze all the fourteen indicators. In order to analyze the competitiveness of companies it is sufficient to observe four among five analyzed specific indicators, i.e. investment rate in the national economy, the participation of companies (companies of the non-financial sector) receiving orders using computer networks (Internet website, such systems as EDI) in companies altogether, average participation of innovative companies in the total number of industrial companies and from the service sector as well as the percentage of industrial companies that cooperated with one another in the sphere of investment activity.

Additionally, the results of soft model show which of the investment priorities $(3 \mathrm{a}, 3 \mathrm{~b}$ or $3 \mathrm{c})$ is the most important for the development of urban functional areas. Naturally, the highest level of factor loadings occurs in case of the total allocation of ITI for the thematic objective $3(0,9929)$. However, from the perspective of the development of entrepreneurship in the analyzed areas an equally important priority is the investment priority $3 \mathrm{a}(0,9296)$. The investment priority $3 \mathrm{c}$ is characterized as having average impact, whereas owing to the low level of allocation within the frameworks of the investment priority $3 \mathrm{~b}$, in the general model it is not essential in the statistical terms. 
It results from its negative statistical verification. The values of factor loadings of strategic indicators creating the synthetic variable "competitiveness of companies" was presented on Graph 1, whereas the synthetic variable "allocation of ITI on CT3" on Graph 2.

GRAPH 1.

The values of factor loadings of strategic indicators creating the synthetic variable "competitiveness of companies"

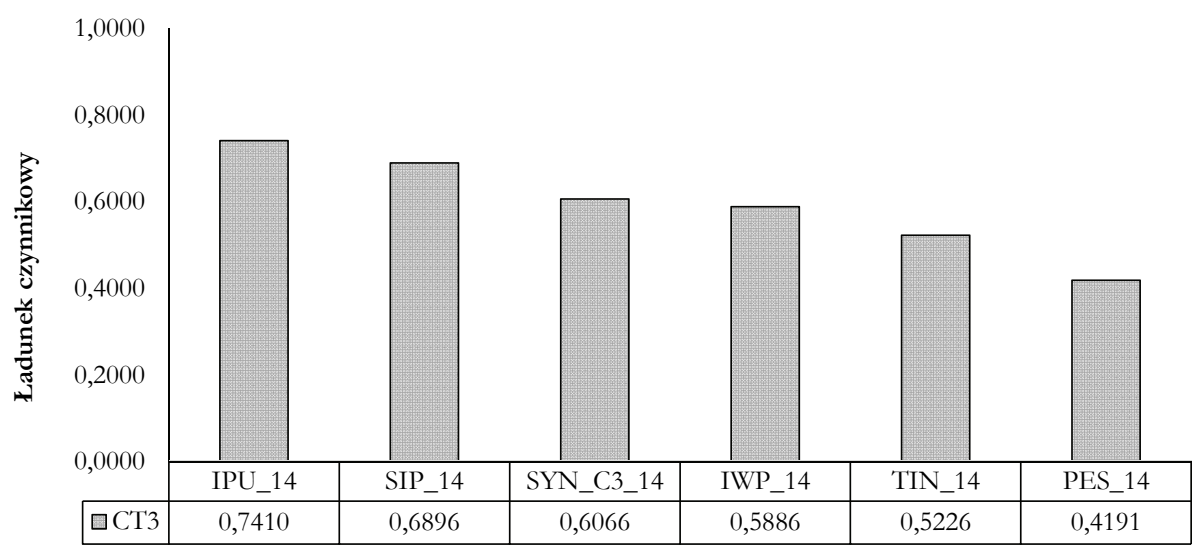

Source: Own elaboration on the basis of the results of soft modelling.

GRAPH 2.

Values of factor loading of strategic indicators forming the synthetic variable "allocation of ITI on CT3" (ITI)

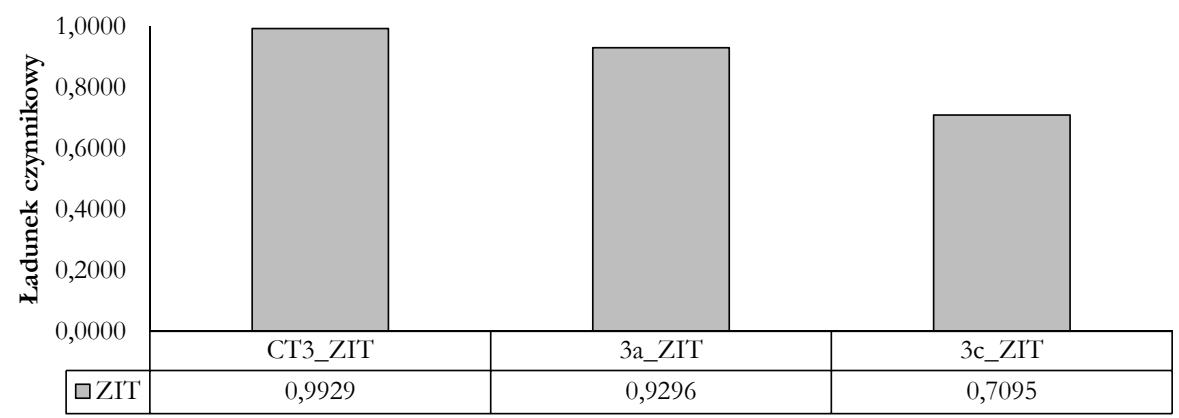

Source: Own elaboration on the basis of the results of soft modelling. 
TABLE 1. The results of estimation of the external model of competitiveness of companies

\begin{tabular}{|c|c|c|c|c|c|}
\hline \multirow{2}{*}{$\begin{array}{l}\text { Synthetic } \\
\text { variable }\end{array}$} & \multirow{2}{*}{ Indicator } & Weight & Factor loading & \multirow{2}{*}{$\begin{array}{c}\text { Free } \\
\text { expression }\end{array}$} & \multirow{2}{*}{$\begin{array}{c}\text { R- } \\
\text { squared }\end{array}$} \\
\hline & & error & error & & \\
\hline \multirow{12}{*}{ CT3 } & \multirow{2}{*}{ SIP_14 } & 0,4010 & 0,6896 & \multirow{2}{*}{9,7895} & \multirow{2}{*}{0,4756} \\
\hline & & 0,0216 & 0,2510 & & \\
\hline & \multirow{2}{*}{ PES_14 } & 0,0081 & 0,4191 & \multirow{2}{*}{4,3785} & \multirow{2}{*}{0,1757} \\
\hline & & 0,0712 & 0,1622 & & \\
\hline & \multirow{2}{*}{ TIN_14 } & 0,4890 & 0,5226 & \multirow{2}{*}{$-3,0252$} & \multirow{2}{*}{0,2731} \\
\hline & & 0,1859 & 0,2351 & & \\
\hline & \multirow{2}{*}{ IPU_14 } & 0,2332 & 0,7410 & \multirow{2}{*}{$-0,2102$} & \multirow{2}{*}{0,5491} \\
\hline & & 0,0590 & 0,0511 & & \\
\hline & \multirow{2}{*}{ IWP_14 } & 0,2507 & 0,5886 & \multirow{2}{*}{0,4690} & \multirow{2}{*}{0,3464} \\
\hline & & 0,2620 & 0,2159 & & \\
\hline & \multirow{2}{*}{ C3_14 } & 0,2376 & 0,6066 & \multirow{2}{*}{$-2,2881$} & \multirow{2}{*}{0,3679} \\
\hline & & 0,0204 & 0,0413 & & \\
\hline \multirow{6}{*}{ ITI } & \multirow{2}{*}{ CT3_ITI } & 0,4223 & 0,9929 & \multirow{2}{*}{0,4333} & \multirow{2}{*}{0,9858} \\
\hline & & 0,0577 & 0,0337 & & \\
\hline & \multirow{2}{*}{ 3a_ITI } & 0,4096 & 0,9296 & \multirow{2}{*}{0,8520} & \multirow{2}{*}{0,8642} \\
\hline & & 0,1424 & 0,0944 & & \\
\hline & \multirow{2}{*}{ 3c_ITI } & 0,2818 & 0,7095 & \multirow{2}{*}{$-0,5773$} & \multirow{2}{*}{0,5034} \\
\hline & & 0,2585 & 0,1654 & & \\
\hline
\end{tabular}

Source: Own elaboration on the basis of the results of soft modelling.

Estimation of the external model of competitiveness level of companies (CT3):

$$
\begin{aligned}
\hat{\mathbf{C}} \mathbf{T} 3= & 0,5436 \mathbf{Z I T}+7,1038 \quad \mathbf{R}^{2}=0,2955 \\
(0,0020) & (2,9246)
\end{aligned}
$$

TABLE 2.

The results of verification of the model of competitiveness level of ompanies using Stone-Geisser test

\begin{tabular}{|c|c|}
\hline Specification & S-G test \\
\hline SIP_14 & 0,0967 \\
PES_14 & 0,0111 \\
TIN_14 & 0,0505 \\
IPU_14 & 0,0582 \\
IWP_14 & 0,0251 \\
SYNC3_14 & 0,0307 \\
General S-G test & 0,0509 \\
\hline
\end{tabular}

Source: Own elaboration on the basis of the results of soft modelling.

The results obtained from the estimation of the internal model of competitiveness level of companies are in line with the expectations. They point at considerable anticipated influence of Integrated Territorial Investments realized by urban functional areas on the level of the competitiveness of companies. The model's quality analyzed 
using the determination coefficient is not high, which is frequently observed in case of the analyses based on spatial data.

MAP 1.

Division of voivodeships into classes in accordance with the synthetic indicator of the "competitiveness of companies" (CT3)

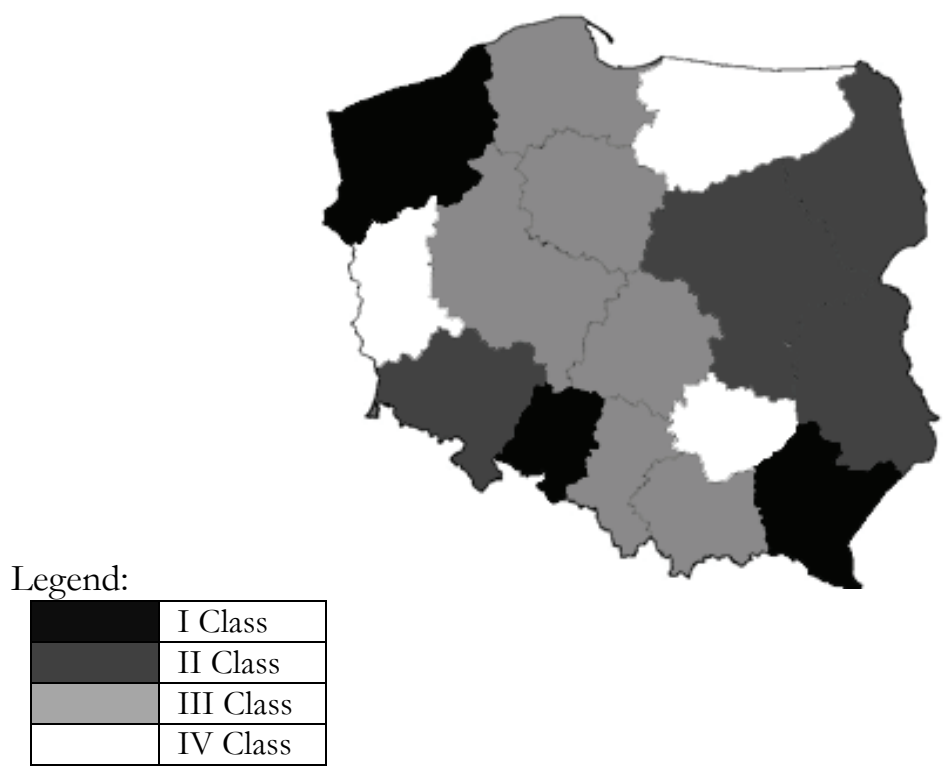

Source: Own elaboration on the basis of the results of soft modelling.

The final effect obtained on the basis of the results of soft model of the competitiveness level of companies (CT3) is the division of voivodeships into classes in accordance with the anticipated relative level of the competitiveness of companies with regards to the realization of projects financed using ITI instrument in CT3 sphere. Voivodeships are divided into particular classes:

- Class I: Podkarpackie, Opolskie and Zachodniopomorskie;

- $\quad$ Class II: Dolnoślaskie, Mazowieckie, Podlaskie and Lubelskie;

- Class III: Kujawsko-Pomorskie, Lódzkie, Małopolskie, Pomorskie, Wielkopolskie and Śląskie;

- Class IV: Lubuskie, Świętokrzyskie and Warmińsko-Mazurskie.

In the first class and second class there are located regions in which major investments in CT3 financed from ITI/RTI are planned. In the third class there are regions that identified other priorities as crucial from the perspective of their development and at the same time display a relatively high level of competitiveness of companies. Class IV comprises voivodeships with the lowest level of the competitiveness of companies in Poland that did not plan any activities financed within the frameworks of the Thematic Objective 3 owing to other considerable needs diagnosed in the ITI strategies. 


\section{The competitiveness of companies in urban functional areas in Poland - TOPSIS method}

For the construction of the synthetic measure of "competitiveness of companies" (CT3) using TOPSIS method there were initially selected six indicators: SIP_14, PES_14, TIN_14, IPU_14, IPW_14, C3_14, for the construction of the measure "allocation of ITI on CT3" three indicators were selected: CT3_ITI, 3a_ITI, 3c_ITI. These are indicators that were firstly used in the soft model. In the further stage the adopted diagnostic features were verified owing to the variability and correlation between them. For the assessment of the mutual correlation of selected features there was selected method of inverse matrix of correlation coefficients [Młodak 2016]. As the result of substantive and statistical verification, i.e. taking into consideration substantive importance, considerable variability of indicators and low values of diagonal elements of matrix inverse for the construction of synthetic measures using TOPSIS method there were used all the indicators. The indicators present in the analysis were in the subsequent stage of the analysis subjected to the normalization process in accordance with the formula (5). Afterwards, while having normalized values of indicators the synthetic measure was calculated and linear ordering of regions was made owing to its value. The values of the synthetic measure of "competitiveness of companies" (CT3) and the measure of allocation of ITI on CT3 (ITI) were presented on graph 3.

GRAPH 3.

The values of synthetic indicator of "the competitiveness of companies" (CT3) and the indicator of "the allocation of ITI in CT3" (ITI)

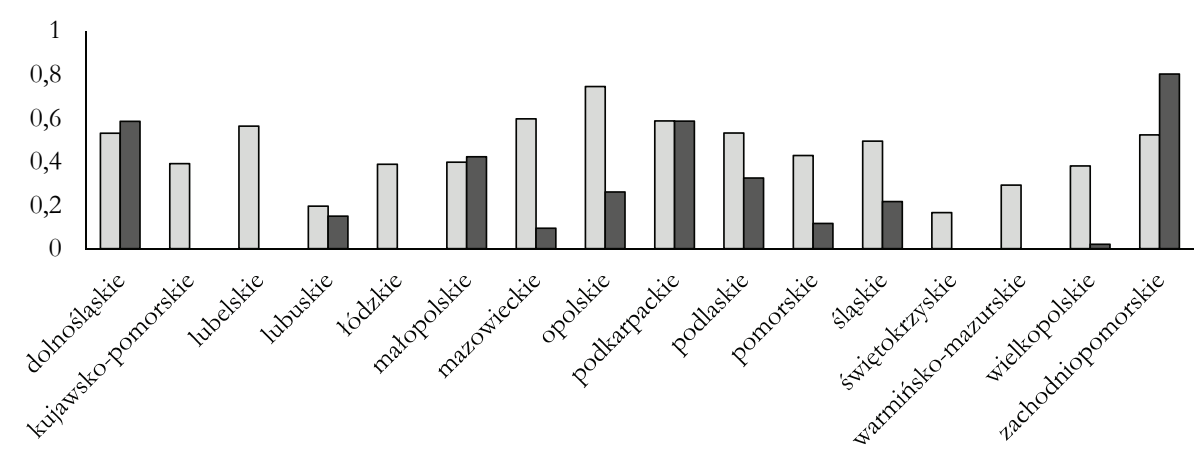

$\square$ CT3 $\square$ ZIT

Source: Own elaboration on the basis of the results obtained using TOPSIS method.

The values of calculated synthetic indicators in particular voivodeships are presented in table 2. By using the arithmetic mean and standard deviation from the value of synthetic indicators districts were divided into 4 classes: with high, medium, upper medium, lower medium and low level of the occurrence of a certain phenomenon. Using various shades of grey voivodeships were divided into typological classes (table 3). 
TABLE 3.

The values of synthetic measure CT3 and ITI obtained using TOPSIS method and ranking of voivodeships

\begin{tabular}{|c|c|c|c|c|}
\hline Voivodeship & $\begin{array}{c}\mathrm{CT} 3 \\
\text { measure }\end{array}$ & Rank & ITI measure & Rank \\
\hline dolnośląskie & $\mathrm{c}$ & 6 & 0,585 & 3 \\
\hline kujawsko-pomorskie & 0,390 & 11 & 0,000 & 12 \\
\hline lubelskie & 0,563 & 4 & 0,000 & 12 \\
\hline lubuskie & 0,195 & 15 & 0,149 & 8 \\
\hline łódzkie & 0,388 & 12 & 0,000 & 12 \\
\hline małopolskie & 0,397 & 10 & 0,422 & 4 \\
\hline mazowieckie & 0,596 & 2 & 0,094 & 10 \\
\hline opolskie & 0,745 & 1 & 0,260 & 6 \\
\hline podkarpackie & 0,587 & 3 & 0,586 & 2 \\
\hline podlaskie & 0,531 & 5 & 0,324 & 5 \\
\hline pomorskie & 0,427 & 9 & 0,116 & 9 \\
\hline śląskie & 0,494 & 8 & 0,216 & 7 \\
\hline świętokrzyskie & 0,166 & 16 & 0,000 & 12 \\
\hline warmińsko-mazurskie & 0,292 & 14 & 0,000 & 12 \\
\hline wielkopolskie & 0,380 & 13 & 0,020 & 11 \\
\hline zachodniopomorskie & 0,523 & 7 & 0,802 & 1 \\
\hline $\min$ & 0,166 & & 0,000 & \\
\hline $\max$ & 0,745 & & 0,802 & \\
\hline rozstęp & 0,579 & & 0,802 & \\
\hline średnia & 0,450 & & 0,223 & \\
\hline odchylenie standardowe & 0,152 & & 0,255 & \\
\hline współczynnik zmienności & 33,77 & & 114,00 & \\
\hline
\end{tabular}

Source: Own elaboration on the basis of the results obtained using TOPSIS method.

The conducted research facilitate the formulation of the conclusion implying that voivodeships in Poland are diversified in terms of the way CT3 and ITI measure are shaping. The scattering of the values of the synthetic measure of development specified using TOPSIS method is greater for ITI $(0,802)$ than for CT3 $(0,579)$. The coefficient of variation calculated on the basis of relative measures amounts to $33,77 \%$ for CT3 and $114 \%$ for ITI. High competitiveness level of companies (CT3) was observed in Opolskie voivodeship, upper medium level is represented by the following voivodeships: Dolnośląskie, Lubelskie, Mazowieckie, Podkarpackie, Podlaskie, Śląskie and Zachodniopomorskie. Lower medium level class in terms of the competitiveness of regions was observed in the following voivodeships: Kujawsko-Pomorskie, Lódzkie, Małopolskie, Pomorskie and Wielkopolskie, whereas the low class is represented by Lubuskie, Świętokrzyskie and Warmińsko-Mazurskie voivodeship. In terms of the ITI indicator, high level is represented by three voivodeships: Dolnośląskie, Podkarpackie and Zachodniopomorskie. Upper medium level is in Małopolskie, Ppolskie and Podlaskie voivodeship. The remaining voivodeships were classified into the class of low level. It needs to be 
emphasized that for five voivodeships (Kujawsko-Pomorskie, Lubelskie, Lódzkie, Świętokrzyskie, Warmińsko-Mazurskie) the indicator value amounts to 0 .

FIGURE 1.

The relations between CT3 and ITI standards of measurement obtained using TOPSIS method

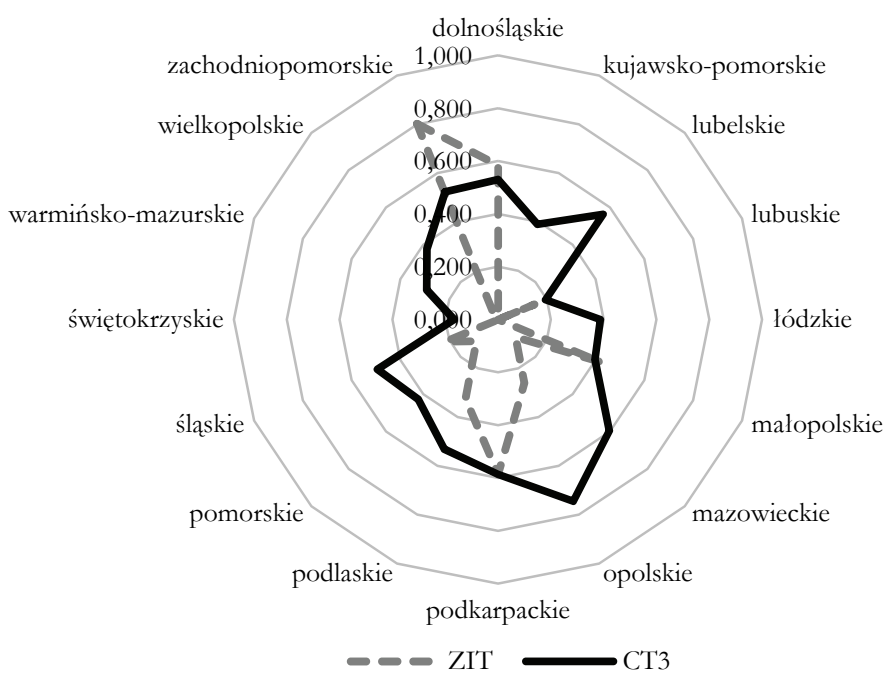

Source: Own elaboration on the basis of the results obtained using TOPSIS method.

Pearson coefficient between CIT and ITI amounts to 0,423 , which indicates moderate relation between these standards of measurement.

\section{Comparative analysis}

The application of these two methods resulted in insignificant differences regarding the positions taken by voivodeships in particular rankings. While adopting the positions of voivodeships as the basis of the comparisons the obtained values of Spearman's correlation coefficient amount to 0,912 for CT3 and 0,956 for ITI (graph 4).

The ranking of voivodeships in terms of $\mathrm{C} 3$ obtained by using both methods shows that the same position in the ranking was occupied by the following voivodeships: opolskie (1), podkarpackie (3), lubelskie (4), pomorskie (9), warmińsko-mazurskie (14), lubuskie (15), świętokrzyskie (16), whereas owing to ITI the ranking comprised: zachodniopomorskie (1), podkarpackie (2), dolnośląskie (3), podlaskie (5), opolskie (6), Śląskie (7), Lubuskie (8), Pomorskie (9), Wielkopolskie (11), Lubelskie (12) and Małopolskie (14) voivodeships. 
GRAPH 4.

The dependence of the positions of voivodeships in Poland in terms of synthetic indicators CT3 and ITI obtained by using soft modeling (SM) and TOPSIS method

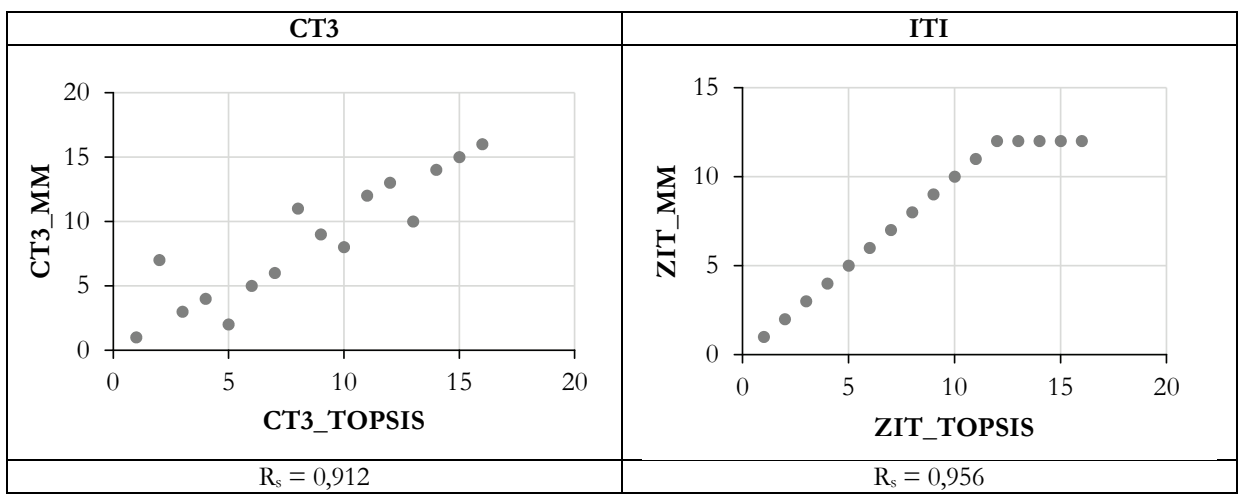

Source: own elaboration on the basis of own calculations.

The most considerable difference in the occupied positions regarded Zachodniopomorskie voivodeship (5 positions) for the CT3 indicator and Świętokrzyskie voivodeship (4 positions) for the ITI indicator.

The obtained results confirm the hypothesis concerning the application of two various methods: soft modelling and TOPSIS method for the analysis of competitiveness of companies in urban functional areas. Owing to the fact that in the analysis made using two selected methods the same diagnostic variables were used, the final results in the form of rankings are particularly similar. The observed differences result from the methodological bases of the applied research instruments. In soft modelling the values of hidden variables depend on both the internal and external relations (i.e. the values of hidden variables CT3 and ITI are relative), whereas in TOPSIS method - two synthetic variables (ITI and CT3) were constructed discretely.

\section{Conclusions}

For the classification of objects with regards to the competitiveness level of companies and the level of allocation of Integrated Territorial Investments for the Thematic Objective 3 of the European Union there were used two methods: soft modeling and TOPSIS method. On the basis of the analysis of the program documents there were selected observable variables aggregated as synthetic measures: "the competitiveness of companies" (CT3) and "the allocation of ITI for CT3" (CT3). Identical diagnostic properties were used in soft modeling and in TOPSIS method.

The formulated soft model of the competitiveness level of companies in urban functional areas shows the impact of the anticipated investments financed within the 
frameworks of the ITI instrument on the increase of the competitiveness of companies. All the non-observable and observable variables were positively verified, both in a substantive and statistic way, which enabled the analysis of the obtained results.

The impact of ITI instrument on increasing the competitiveness of companies is positive and moderate. This result ought to be assessed as positive and anticipated. Not all the municipalities realizing the Integrated Territorial Investments are involved in the tasks related to СТ3. Therefore, in case of some urban functional areas the level of ITI allocation amounted to zero (this regards UFA in the following voivodeships: Kujawsko-Pomorskie, Lubelskie, Lódzkie, Świętokrzyskie and Warmińsko-Mazurskie). The development of functional areas is the resultant of the activity taken not only by ITI unions, but also by particular municipalities that realize the tasks related, among others, to the creation of conditions increasing the competitiveness of companies. In this process the importance of companies, institutions from the business environment and other organizations (e.g. clusters) can not be overlooked. The involvement of various participants and the diversification of the sources of financing the development of UFA may contribute to the achievement of the added value in the form of the synergy effect.

The application of soft modelling and TOPSIS method resulted in obtaining a similar position of voivodeships in the ranking owing to the analyzed synthetic variables.

The analysis conducted in a systematic way using the described methods for subsequent time periods will enable the analysis of the dynamics and directions of implementing the instrument of Integrated Territorial Investments and its real impact on the competitiveness level of companies.

\section{The authors' participation in the preparation of the article}

Dorota Perło, $\mathrm{PhD}$ - participation in development of the research concept, literatury review, summary, introduction, first chapter, second chapter in part of soft modelling, chapter three, participation in chapter five, conclusions $-60 \%$

Ewa Roszkowska, PhD, Professor of the University of Bialystok - participation in development of the research concept, literatury review, second chapter in part of TOPSIS method, chapter four, participation in chapter five $-40 \%$

\section{References}

Dębkowska K., Jarocka M., 2013, The impact of the methods of the data normalization on the result of linear ordering, "Acta UL. Fol. Oecon", No. 286.

Hwang C.L., Yoon K., 1981, Multiple Attribute Decision Making: Methods and Applications, Springer-Verlag, New York.

Joreskog K.G., Wold H., 1982, Systems under indirect observation. Causality - Structure Prediction, Part II, North-Holland.

Kolenda M., 2006, Taksonomia numeryczna. Klasyfikacja, porzadkowanie $i$ analiza obiektów wielocechonych, Wydawnictwo Akademii Ekonomicznej im. Oskara Langego we Wrocławiu, Wrocław. 
Kuszewski T., 2000, Wprowadzenie do modelowania ekonometrycznego, [w:] Ekonometria, M. Gruszczyński, M. Podgórska (red.), Oficyna Wydawnicza SGH, Warszawa. Lubiński M., 1995, Konkurencyjnośc gospodarki. Pojecia i sposoby mierzenia, IRiSS, Warszawa. Luka konkurencyjna na poziomie przedsiębiorstwa a praystapienie Polski do Unii Europejskiej 2002, M. Gorynia (red.), Wydawnictwo Akademii Ekonomicznej w Poznaniu, Poznań. Młodak A., 2006, Analiza taksonomiczna w statystyce regionalnej, Difin, Warszawa.

Monitorowanie strategiczne miejskich obszarów funkcjonalnych realizujacych Zintegrowane Inwestycje Terytorialne w Polsce. Badanie pilotażowe. Cel tematyczny 3: Wrorost konkurencyjności przedsiębiorstw. Raport 1. Wskaźniki strategiczne na poziomie wojewódz̨tw grudzień 2016, D. Mierzyńska, D. Perło, T. Truskolaski (red.), Stowarzyszenie Białostockiego Obszaru Funkcjonalnego, Białystok.

Panek T., 2009, Statystyczne metody wielonymiarowej analizy porównawczej, Szkoła Główna Handlowa w Warszawie, Warszawa.

Perło D., 2014, Modelowanie zrównoważonego rožnoju regionów, Wydawnictwo Trans Humana, Białystok.

Programowanie perspektymy finansowej 2014-2020 - Umowa Partnerstwa, 2014, Ministerstwo Infrastruktury i Rozwoju, Warszawa.

Rogowski J., 1990, Modele miekkeie. Teoria i zastosowanie w badaniach ekonomicznych, $\mathrm{W}_{\mathrm{y}-}$ dawnictwo Filii UW w Białymstoku, Białystok.

Rogowski J., 2002, Modele miekekie w budowie strategii finansowej regionu, „Optimum. Studia Ekonomiczne", nr 1.

Rozporządzenie Parlamentu Europejskiego i Rady (UE) Nr 1301/2013 z dnia 17 grudnia 2013 r. w sprawie Europejskiego Funduszu Rozwoju Regionalnego i przepisów szczególnych dotyczących celu „Inwestycje na rzecz wzrostu i zatrudnienia” oraz w sprawie uchylenia rozporzadzenia (WE) nr 1080/2006.

Rozporządzenie Parlamentu Europejskiego i Rady (UE) Nr 1303/2013 z 17 grudnia 2013 r. ustanawiające wspólne przepisy dotyczące Europejskiego Funduszu Rozwoju Regionalnego, Europejskiego Funduszu Społecznego, Funduszu Spójności, Europejskiego Funduszu Rolnego na rzecz Rozwoju Obszarów Wiejskich oraz Europejskiego Funduszu Morskiego i Rybackiego oraz ustanawiające przepisy ogólne dotyczące Europejskiego Funduszu Rozwoju Regionalnego, Europejskiego Funduszu Społecznego, Funduszu Spójności i Europejskiego Funduszu Morskiego i Rybackiego oraz uchylające rozporządzenie Rady (WE) nr 1083/2006.

Rozporządzenie Parlamentu Europejskiego i Rady (UE) Nr 1304/2013 z dnia 17 grudnia 2013 r. w sprawie Europejskiego Funduszu Społecznego i uchylające rozporządzenie Rady (WE) nr 1081/2006.

Stankiewicz M.J., 2000, Istota i sposoby oceny konkurencyjności przedsiebiorstwa, „Gospodarka Narodowa", nr 7-8.

Ustawa z dnia 11 lipca 2014 r. o zasadach realizacji programów w zakresie polityki spójności finansowanych w perspektywie finansowej 2014-2020, Dz.U., 2014, poz. 1146).

Wold H., 1980, Soft Modelling: Intermediate between Traditional Model Building and Data Analysis, Banach Centre Publication 6, Mathematical Statistics. 